\title{
Preferensi, Persepsi, dan Harapan Pengguna Terhadap Rumah Sakit Ibu dan Anak (RSIA)
}

\section{User's Preference, Perception, and Expectation for Mother and Children's Hospital}

\section{Intan Reyndan Fananti*}

Sekolah Arsitektur, Perencanaan, dan Pengembangan Kebijakan (SAPPK), Institut Teknologi Bandung, Indonesia, intanrf1402@gmail.com

Annisa Safira Riska

Sekolah Arsitektur, Perencanaan, dan Pengembangan Kebijakan (SAPPK), Institut Teknologi Bandung, Indonesia, annisa.safira.riska@gmail.com

\section{Hanson Endra Kusuma}

Sekolah Arsitektur, Perencanaan, dan Pengembangan Kebijakan (SAPPK), Institut Teknologi Bandung, Indonesia, hekusuma@gmail.com

*correspondence author

\begin{abstract}
The hospital building is designed to fulfill and accommodate every user's needs, suchs the patients and othergeneral users/visitors. The users discussed in this research are patients and general users. This research aims to determine preferences (reasons for choosing), perceptions (strengths and weaknesses), and users' expectations (patients and general users) of Mother \& Child Hospital. The research was conducted qualitatively using a grounded theory approach. Data were collected using an online questionnaire containing open-ended main questions and distributed freely (non-random sampling). The collected data were analyzed qualitatively using the content analysis (open coding) method. The results show Mother \& Children Hospital's patient and general user's differences in preferences, perception, and expectations on visual architectural aspects, non-visual architectural aspects, and nonarchitectural aspects. The preferences, perceptions, and expectations of patients and general users tend to be non-architectural in terms of their preferences. There is only one difference, it's in the general user's perception of the Mother \& Children Hospital's weakness, where the perception lies in the visual architectural aspect. The tendency for patients and general users are found in the category of service, facilities, quality of medical personnel, location, and parking
\end{abstract}

Keywords: expectation, general user, patient, perception, preference

Abstrak

Bangunan rumah sakit dirancang untuk memenuhi dan mengakomodasi seluruh kebutuhan penggunanya. Pengguna yang dibahas dalam penelitian ini adalah pasien dan pengunjung umum. Penelitian ini ditujukan untuk mengetahui preferensi (alasan memilih), persepsi (kelebihan dan kekurangan), dan harapan pengguna (pasien dan pengunjung) terhadap Rumah Sakit Ibu dan Anak (RSIA). Penelitian dilakukan secara kualitatif dengan menggunakan pendekatan grounded theory. Data dikumpulkan menggunakan kuesioner daring yang berisi pertanyaan utama yang bersifat terbuka (open-ended) dan dibagikan secara bebas (non-random sampling). Kemudian data yang terkumpul dianalisis secara kualitatif menggunakan metode analisis isi. Hasil menunjukkan perbedaan preferensi, persepsi, dan harapan pasien dan pengunjung RSIA terhadap aspek visual arsitektural, aspek non-visual arsitektural, dan aspek non-arsitektural. Kecenderungan preferensi, persepsi, dan harapan pasien maupun pengunjung umum adalah pada aspek non arsitekturalnya. Hanya terdapat satu perbedaan, yaitu pada persepsi pengunjung umum terhadap kekurangan RSIA, di mana persepsi terletak pada aspek visual arsitekturalnya.

Preferensi, Persepsi, dan Harapan Pengguna Terhadap Rumah Sakit Ibu dan Anak (RSIA) 
Kecenderungan pasien maupun pengunjung terdapat pada kategori pelayanan, fasilitas, kualitas tenaga medis, lokasi, dan parkir.

Kata Kunci: harapan, pasien, pengunjung, persepsi, preferensi

Received: 2021-03-18 | Accepted: 2021-06-17 | DOI: 10.29080/eija.v7i1.1195 | Page: 25-41

EMARA: Indonesian Journal of Architecture

http://jurnalsaintek.uinsby.ac.id/index.php/EIJA

This article is open access distributed under the terms of the Creative Commons Attribution ShareAlike 4.0 International License, which permits unrestricted use, distribution, and reproduction in any medium provided the original work is properly cited.

\section{Pendahuluan}

Bangunan rumah sakit harus memenuhi aspek standar keamanan, kenyamanan, kesehatan kerja, keselamatan, dan pelayanan sehingga dapat berfungsi secara optimal (Kusumaningrum \& Martiningrum, 2017). Tidak hanya itu, bangunan rumah sakit pun perlu mempertimbangkan kepentingan pengguna sebagai tujuan utama dalam merencanakan bangunan Rumah Sakit Ibu dan Anak (RSIA). Pengguna yang dimaksud adalah pelaku yang mendapatkan dan merasakan pelayanan serta fasilitas dalam RSIA, yaitu pasien dan pengunjung umum. Pasien merupakan pengguna yang datang dengan tujuan utama mendapatkan pelayanan serta fasilitas pada RSIA, sedangkan pengunjung umum merupakan pengguna yang datang dengan tujuan lain, rata-rata sebagai pengantar pasien.

Rumah Sakit Ibu dan Anak (RSIA) termasuk dalam kategori Rumah Sakit Khusus, yang merupakan fasilitas untuk melayani dan memenuhi kebutuhan pasien (ibu, bayi, dan anak umur 0-18 tahun) pada masa proses persalinan (mulai dari pra kehamilan, kehamilan, persalinan), perawatan ibu dan bayi, tumbuh kembang anak, imunisasi, KB, serta permasalahan penyakit yang berhubungan dengan obstetric dan ginekologi (kandungan dan kebidanan), juga melayani konsultasi kesehatan mengenai masalah reproduksi di mana semua pelayanan kesehatan tersebut harus memenuhi standar pelayanan kesehatan (Estiningtyas, 2010).

Preferensi merupakan sesuatu yang disukai atau pilihan seseorang, di mana hal ini berhubungan erat dengan suatu fasilitas (Wardhani et al., 2015). Dalam penelitian ini, preferensi adalah alasan seseorang memilih RSIA yang akan dikunjungi.

Persepsi merupakan sebuah proses yang dilakukan seseorang dalam memahami informasi mengenai lingkungannya, yang menyebabkan seseorang menata ulang hal-hal tersebut untuk mendefinisikan pemikirannya (Wardhani et al., 2015). Dalam penelitian ini, persepsi adalah kelebihan dan kekurangan dari RSIA yang dikunjungi oleh pengguna.

Sedangkan harapan atau ekspektasi adalah suatu keyakinan seseorang atau individu dalam suatu hal yang seharusnya terjadi dalam situasi yang sedang dihadapi (Sutisna, 2001). Dalam penelitian ini, harapan adalah keinginan masing-masing pengguna (pasien dan pengunjung umum) untuk pengalaman yang berbeda, mulai dari pelayanan, fasilitas, dan lain sebagainya terhadap RSIA yang akan dikunjungi.

Ketiga hal di tersebut (preferensi, persepsi, dan harapan) yang disebutkan oleh pengguna (pasien dan pengunjung umum) RSIA saling berkaitan untuk menghasilkan beberapa aspek yang 
berguna untuk perancangan RSIA yang lebih baik kedepannya, berdampingan dengan Peraturan Pemerintah mengenai bangunan Rumah Sakit yang telah ada. Meskipun pemahaman tentang preferensi, persepsi, dan harapan terhadap RSIA akan dapat meningkatkan kinerja perencanaan ataupun perancangan RSIA; Penelitian ini dilakukan juga untuk mengetahui preferensi, persepsi, dan harapan pengguna terhadap Rumah Sakit Ibu dan Anak (RSIA). Hal ini akan dibagi dalam 3 aspek ; visual arsitektural, non visual arsitektural, dan non arsitektural. Aspek visual arsitektural adalah suatu hal yang dapat dilihat langsung oleh mata. Pada aspek ini, ada elemen titik fokus, garisgaris, bentuk, warna, dan tekstur, di mana elemen-elemen ini akan membentuk suatu karakteristik unik yang membedakan satu desain dengan yang lain (Ginting \& Priatna, 2019) Sedangkan aspek nonvisual arsitektural adalah kebalikan dari aspek visual arsitektural, yaitu elemen yang tidak dapat dilihat langsung oleh mata, namun dapat dirasakan. Contohnya adalah kebutuhan fisiologis (sandang, pangan, papan), rasa aman, kepercayaan dan cinta kasih (belongingness \& love needs), kebutuhan akan harga diri (self esteem), kebutuhan mengetahui dan memahami, kebutuhan aktualisasi diri, dan kebutuhan akan kelebihan (Maslow, 2010). Terakhir, Aspek non arsitektural adalah hal yang sama sekali tidak berhubungan dengan arsitektur. Dalam penelitian ini, contoh aspek non arsitektural antara lain ; pelayanan, fasilitas - di mana fasilitas merupakan kebutuhan kesehatan yang telah ditentukan dalam standar pemerintah, yaitu pedoman teknis sarana dan prasarana rumah sakit umum dan khusus..

\section{Metode}

Penelitian ini dilakukan secara kualitatif dengan pendekatan grounded theory (Creswell \& Creswell, 2017).. Grounded theory adalah sebuah metode penelitian kualitatif yang bertujuan untuk menghasilkan penjelasan umum atau teori dari suatu fenomena, proses, tindakan atau interaksi yang diperoleh dari responden. Data yang sudah terkumpul akan di analisis, ditafsirkan, kemudian disusun dalam model hipotesis. Pada penelitian ini, data yang terkumpul adalah persepsi atau preferensi pengguna terhadap Rumah Sakit Ibu dan Anak (RSIA) yang dikunjungi serta harapan mengenai RSIA yang ideal.

Pengumpulan data dilakukan menggunakan metode non-random sampling dengan teknik accidental sampling (Creswell \& Creswell, 2017). Accidental adalah teknik penentuan data/sampel secara kebetulan, dengan kata lain, siapa saja yang secara kebetulan bertemu yang dianggap cocok dengan karakteristik pertanyaan yang telah ditentukan (Kumar, 2010). Langkah dilakukan dengan pengumpulan data melalui penyebaran kuesioner daring (online) dengan google form. Kuesioner daring bersifat terbuka (open-ended), di mana responden yang diminta menjawab pertanyaan dapat berpendapat seluasluasnya, tanpa batasan. Proses ini dilakukan hingga mencapai target jumlah tertentu dan dalam jangka waktu tertentu juga. Melalui kuesioner ini, diharapkan jawaban yang didapat akan sesuai dengan hal yang dipikirkan dan dirasakan oleh responden mengenai preferensi, persepsi, dan harapan terhadap RSIA.

Kuesioner daring (online) ini dibagikan pada media sosial dengan batasan khusus, yaitu hanya dapat diisi oleh responden yang sudah pernah mengunjungi RSIA. Namun, untuk identitas responden, tidak ada batasan usia, jenis kelamin, pekerjaan, pendidikan, serta pendapatan. Proses pengumpulan 
data kuesioner daring ini dilakukan dalam kurun waktu 8 hari, mulai dari tanggal 7 hingga 14 September 2020 dengan jumlah responden sebanyak 126 orang, dengan rincian jumlah responden wanita sebanyak 71 orang dan pria sebanyak 55 orang, usia yang berkisar dari 22 hingga 60 tahun. Pendidikan terakhir mulai dari SMA/SMK hingga Pasca-Sarjana. Status pernikahan mulai dari lajang hingga memiliki anak. Jenis pekerjaan yang bervariasi, yaitu mulai dari mahasiswa, PNS (Pegawai Negeri Sipil), pegawai swasta, pengusaha/wiraswasta, ibu rumah tangga, dan lainnya. Domisili responden yang juga bervariasi, mulai dari DKI Jakarta, Jawa Barat, Jawa Tengah, DI Yogyakarta, Jawa Timur, dan Luar Jawa. Kemudian klasifikasi responden yang mengunjungi RSIA sebagai pasien sebanyak 33 orang dan pengunjung umum (pengantar/pendamping pasien atau lainnya) sebanyak 93 orang.

Data yang didapatkan melalui kuesioner daring ini kemudian dianalisis dengan metode analisis isi (content analysis) yang dilakukan dengan tahap open coding (Creswell, 2012). Tahap open coding merupakan tahap identifikasi segmen makna, pendefinisian dan pengkategorian tiap kata-kunci/kode yang mewakili segmen makna, serta pengelompokan kode yang mirip menjadi kategori. Tahap ini dilakukan menggunakan program atau aplikasi Microsoft Excel dan JMP Statistical Software version 7. Jumlah/frekuensi dari masing-masing kategori disajikan dalam bentuk diagram melalui analisis distribusi.

\section{Hasil dan Pembahasan}

PDari analisis isi pada tahap awal, dilakukan analisis open coding untuk mengidentifikasikan kata-kata kunci/kode dari seluruh data teks jawaban responden. Contoh dari open coding yang diperoleh dari jawaban responden pada pertanyaan alasan memilih RSIA adalah sebagai berikut.

"Fasilitas dan pelayanan nya baik, akses nya mudah, pemberlakuan protokol kesehatan utk pencegahan COVID-19 nya juga diterapkan dengan baik" (Wanita, 24, Pegawai Swasta, Pasien)

"1. Di kota kami (Semarang) RSIA tersebut merupakan RSIA yg cukup ternama. 2. Beberapa testimoni yang positif terhadap RSIA tersebut. 3. Sesuai dengan kemantapan hati." (Pria, 63, Pegawai Negeri, Pengunjung umum)

Berdasarkan kutipan tersebut, didapatkan beberapa kata-kunci/kode, yaitu ; "Fasilitas baik", "Pelayanan baik", "Akses mudah", "Pemberlakuan protokol kesehatan baik", "RSIA ternama", "Testimoni positif", "Sesuai dengan keinginan". Temuan kata-kata kunci kemudian dikelompokkan menjadi kategori. Kelompok kategori akan dibagi menjadi 3 aspek: visual arsitektural, nonvisual arsitektural, dan non-arsitektural.

\section{Preferensi Pengguna Terhadap RSIA Pasien}

Pada analisis open coding preferensi (alasan memilih) pasien terhadap RSIA ditemukan 7 kategori, yaitu: aksesibilitas, fasilitas, kualitas tenaga medis, kualitas RSIA, pelayanan, spesialisasi, dan rekomendasi. (Tabel 1 )

Tabel 1. Hasil open coding preferensi pasien terhadap RSIA.

\begin{tabular}{lll}
\hline No & Kata Kunci/Kode & Kategori \\
\hline 1 & $\begin{array}{l}\text { Akses mudah } \\
\text { Dekat rumah } \\
\text { Searah dengan tujuan }\end{array}$ & Aksesibilitas \\
& $\begin{array}{l}\text { Fasilitas baik } \\
\text { Fasilitas lengkap } \\
\text { Alat medis lengkap } \\
\text { Asuransi }\end{array}$ & \\
\hline & $\begin{array}{l}\text { Dokter langganan } \\
\text { Dokter spesialis } \\
3\end{array}$ & Fokter baik \\
& Dokter berpengalaman & \\
\hline 4 & Kualitas baik & Kualitas Tenaga \\
\end{tabular}


Pelayanan baik

Fleksibilitas waktu

Protokol kesehatan baik

5 Pelayanan ramah

Pelayanan cepat

Pelayanan lengkap

Pegawai ramah

\begin{tabular}{lll}
\hline & Langganan & \\
& Terkenal & \\
& Memilih RSIA dibanding & \\
6 & RSU & Spesialisasi \\
& Lebih aman dibanding & \\
& RSU & \\
& Khusus ibu \& anak & \\
\hline 7 & Rekomendasi & Rekomendasi \\
\hline
\end{tabular}

Sumber: analisis penulis 2020

Hasil analisis distribusi (gambar 1) menunjukkan bahwa alasan pasien memilih RSIA cenderung karena aspek kualitas tenaga medis sebesar 15 (28\%), kemudian disusul oleh aksesibilitas sebesar 10 (19\%), lalu pelayanan dan fasilitas yang masingmasing sebesar 9 (17\%), spesialisasi sebesar 7 (13\%), terakhir adalah masing-masing sebesar 2 (4\%).

Gambar 1. Analisis distribusi kategori alasan pasien memilih RSIA. (sumber: hasil analisis,2020)

\section{Pengunjung Umum}

Pada analisis open coding preferensi (alasan memilih) pengunjung terhadap RSIA ditemukan 11 kategori, yaitu: berkunjung, desain, fasilitas, kebersihan, kenyamanan, kualitas tenaga medis, lokasi, pelayanan, spesialisasi, rekomendasi, dan rujukan. (Tabel 2)

Sedangkan hasil analisis distribusi (gambar 2) menunjukkan bahwa alasan pengunjung umum memilih RSIA cenderung karena aspek pelayanan dan lokasi yang masing-masing berjumlah 22 rekomendasi dan kualitas RSIA yang

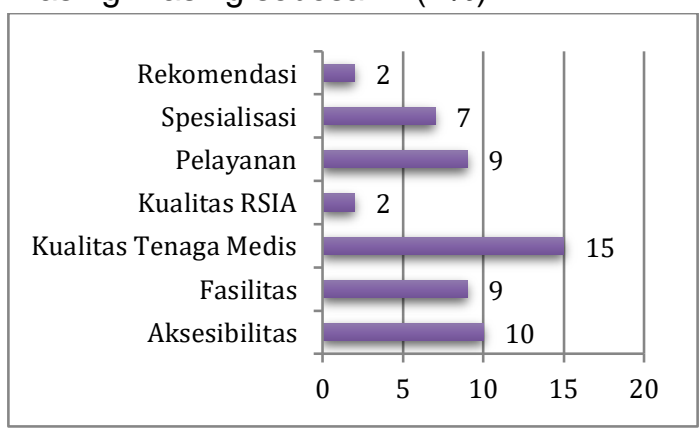

(19\%), kemudian disusul oleh spesialisasi sebesar 19 (16\%), lalu rekomendasi sebesar 11 (9\%), berkunjung sebesar 10 (9\%), kualitas tenaga medis sebesar 9 (8\%), kenyamanan dan fasilitas yang masing-masing sebesar 7 (6\%), kebersihan sebesar 4 (3\%), desain sebesar 3 (3\%), dan terakhir adalah rujukan sebesar $2(2 \%)$.

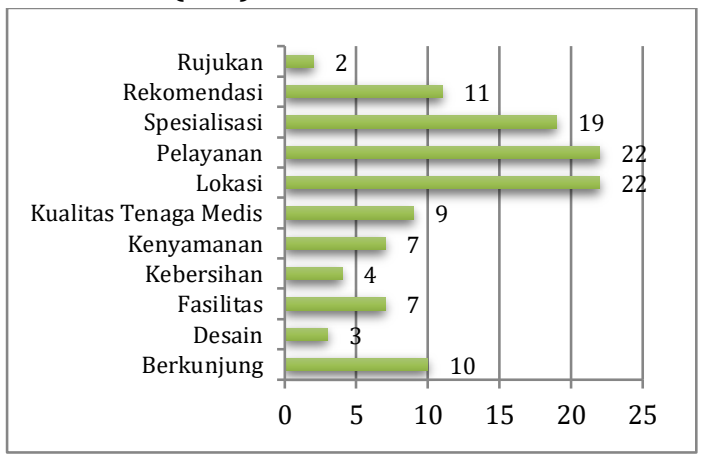

Gambar 2. Analisis distribusi kategori alasan pengunjung umum memilih RSIA (analisis,2020)

Tabel 2. Hasil open coding preferensi pengunjung umum terhadap RSIA

\begin{tabular}{|c|c|c|}
\hline No & Kata Kunci/Kode & Kategori \\
\hline 1 & $\begin{array}{l}\text { Berkunjung } \\
\text { Mengunjungi pasien }\end{array}$ & Berkunjung \\
\hline 2 & $\begin{array}{l}\text { Desain baik } \\
\text { Desain rumah sakit }\end{array}$ & Desain \\
\hline 3 & $\begin{array}{l}\text { Alat medis baik } \\
\text { Fasilitas baik } \\
\text { Fasilitas lengkap }\end{array}$ & Fasilitas \\
\hline 4 & Bersih & Kebersihan \\
\hline 5 & $\begin{array}{l}\text { Kenyamanan } \\
\text { Nyaman } \\
\text { Mengurangi resiko } \\
\text { tertular Covid-19 } \\
\text { Tenang }\end{array}$ & Kenyamanan \\
\hline 6 & $\begin{array}{l}\text { Dokter langganan } \\
\text { Kualitas dokter } \\
\text { Tenaga medis baik }\end{array}$ & $\begin{array}{l}\text { Kualitas Tenaga } \\
\text { Medis }\end{array}$ \\
\hline 7 & $\begin{array}{l}\text { Dekat } \\
\text { Dekat kampus } \\
\text { Dekat rumah } \\
\text { Lokasi strategis }\end{array}$ & Lokasi \\
\hline 8 & $\begin{array}{l}\text { Pelayanan baik } \\
\text { Pelayanan cepat } \\
\text { Pelayanan ramah } \\
\text { Pelayanan rapid test } \\
\text { Pilihan dokter }\end{array}$ & Pelayanan \\
\hline 9 & Asuransi & Spesialisasi \\
\hline
\end{tabular}

Preferensi, Persepsi, dan Harapan Pengguna Terhadap Rumah Sakit Ibu dan Anak (RSIA)

(C) Fanati, Riska \& Kusuma (2020) under the CC BY SA license 


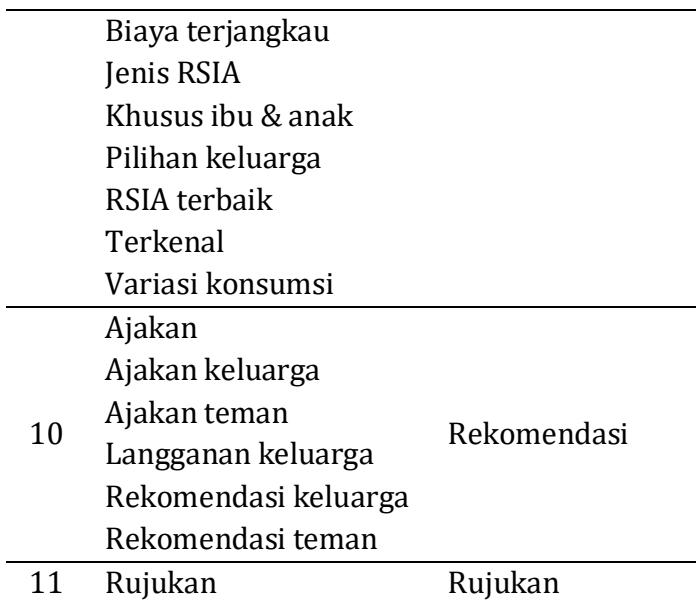

Sumber: hasil analisis penulis, 2020

Perbedaan Preferensi Pasien dan Pengunjung Umum

Alasan terbesar pasien maupun pengunjung umum memilih Rumah Sakit Ibu dan Anak (RSIA) adalah dari aspek non-arsitektural, dengan prosentase pasien sebesar $77 \%$ dan pengunjung umum sebesar $69 \%$. Alasan memilih RSIA mulai dari hanya sekedar berkunjung, fasilitas, kualitas tenaga medis, pelayanan, preferensi, rekomendasi, dan rujukan. Kemudian, sebesar 23\% (pasien) dan 28\% (pengunjung umum) memilih RSIA berdasarkan aspek non-visual arsitekturnya, yaitu aksesibilitas, kualitas RSIA, kebersihan, kenyamanan, dan lokasi. Hanya sebesar 3\% (pengunjung umum) memilih RSIA berdasarkan aspek visual arsitekturalnya, yaitu desain. (Tabel 3) Hal ini dikarenakan pengguna, pasien maupun pengunjung umum memilih RSIA dengan tujuan utama untuk menggunakan fasilitas kesehatannya. Maka, prioritas pengguna dalam memilih RSIA adalah pada pelayanan dan kualitas tenaga medisnya.
Tabel 3. Alasan pasien dan pengguna umum memilih RSIA.

\begin{tabular}{|c|c|c|c|}
\hline 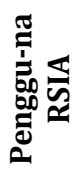 & Kategori & $\%$ & Aspek \\
\hline \multirow[b]{2}{*}{$\frac{a}{\sqrt[0]{2}}$} & $\begin{array}{l}\text { Aksesibilitas } \\
\text { Kualitas RSIA }\end{array}$ & $23 \%$ & $\begin{array}{l}\text { Aspek Non- } \\
\text { Visual } \\
\text { Arsitektural }\end{array}$ \\
\hline & $\begin{array}{l}\text { Fasilitas } \\
\text { Kualitas Tenaga } \\
\text { Medis } \\
\text { Pelayanan } \\
\text { Preferensi } \\
\text { Rekomendasi }\end{array}$ & $77 \%$ & $\begin{array}{l}\text { Aspek Non } \\
\text { Arsitektura }\end{array}$ \\
\hline \multirow{3}{*}{ 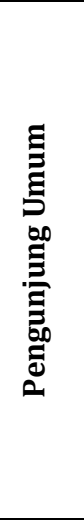 } & Desain & $3 \%$ & $\begin{array}{l}\text { Aspek } \\
\text { Visual } \\
\text { Arsitektural }\end{array}$ \\
\hline & $\begin{array}{l}\text { Kebersihan } \\
\text { Kenyamanan } \\
\text { Lokasi }\end{array}$ & $28 \%$ & $\begin{array}{l}\text { Aspek Non- } \\
\text { Visual } \\
\text { Arsitektura } \\
\end{array}$ \\
\hline & $\begin{array}{l}\text { Berkunjung } \\
\text { Fasilitas } \\
\text { Kualitas Tenaga } \\
\text { Medis } \\
\text { Pelayanan } \\
\text { Preferensi } \\
\text { Rekomendasi } \\
\text { Rujukan }\end{array}$ & $69 \%$ & $\begin{array}{l}\text { Aspek Non } \\
\text { Arsitektura }\end{array}$ \\
\hline
\end{tabular}

Sumber: hasil analisis penulis, 2020

Pasien dan pengunjung umum memiliki perbedaan prioritas dalam memilih RSIA. Pasien yang memiliki tujuan utama untuk periksa kesehatan tentu saja memprioritaskan kualitas tenaga medisnya. Karena kualitas tenaga medis yang baik akan berpengaruh positif terhadap kepuasan penggunanya (Maulana, 2016). Tidak adanya aspek visual arsitektural pada tujuan pasien memilih RSIA menandakan bahwa keindahan atau estetika RSIA bukan merupakan sebuah prioritas. Sedangkan pengunjung umum yang tidak berhubungan langsung dan berkepentingan dengan pemeriksaan kesehatan, memprioritaskan pelayanan dan lokasi. Selain itu, pengunjung umum pun memprioritaskan lokasi. Karena pengunjung memilih lokasi yang strategis atau dekat dengan tempat tinggalnya 


\section{Preferensi Pengguna Terhadap Kelebihan RSIA \\ Pasien}

Pada analisis open coding persepsi pasien terhadap kelebihan RSIA yang dikunjungi ditemukan 8 kategori, yaitu: biaya terjangkau, desain, fasilitas, kebersihan, kenyamanan, kualitas tenaga medis, lokasi, dan pelayanan. (Tabel 4)

Tabel 4. Hasil open coding persepsi pasien terhadap kelebihan RSIA yang dikunjungi.

\begin{tabular}{|c|c|c|}
\hline No & Kata Kunci & Kategori \\
\hline 1 & Biaya terjangkau & $\begin{array}{l}\text { Biaya } \\
\text { Terjangkau }\end{array}$ \\
\hline 2 & $\begin{array}{l}\text { Parkir luas } \\
\text { Parkir mudah }\end{array}$ & Desain \\
\hline 3 & $\begin{array}{l}\text { Ada tempat bermain } \\
\text { anak } \\
\text { Ada spa bayi } \\
\text { Ada spa ibu } \\
\text { Alat medis lengkap } \\
\text { Fasilitas baik } \\
\text { Fasilitas lengkap } \\
\text { Makanan rawat inap } \\
\text { baik }\end{array}$ & Fasilitas \\
\hline 4 & Bersih & Kebersihan \\
\hline 5 & $\begin{array}{l}\text { Nyaman } \\
\text { Tenang }\end{array}$ & Kenyamanan \\
\hline 6 & $\begin{array}{l}\text { Dokter baik } \\
\text { Dokter berpengalaman } \\
\text { Pilihan dokter } \\
\text { Tenaga medis baik }\end{array}$ & $\begin{array}{l}\text { Kualitas Tenaga } \\
\text { Medis }\end{array}$ \\
\hline 7 & $\begin{array}{l}\text { Dekat rumah } \\
\text { Lokasi strategis } \\
\text { Lokasi terjangkau }\end{array}$ & Lokasi \\
\hline 8 & $\begin{array}{l}\text { Ada layanan tertentu } \\
\text { Asuransi } \\
\text { Pelayanan } \\
\text { Pelayanan baik } \\
\text { Pelayanan cepat } \\
\text { Pelayanan ramah }\end{array}$ & Pelayanan \\
\hline
\end{tabular}

Sumber: analisis penulis, 2020

Hasil analisis distribusi (Gambar 3) menunjukkan bahwa persepsi pasien terhadap kelebihan RSIA cenderung karena aspek pelayanan sebesar 20 (31\%), kemudian disusul oleh kualitas tenaga medis sebesar 15 (23\%), lalu fasilitas sebesar 13 (20\%), lokasi, kenyamanan, dan kebersihan yang masing-masing sebesar 5 (8\%), dan terakhir adalah desain dan biaya terjangkau yang masing-masing sebesar $1(2 \%)$

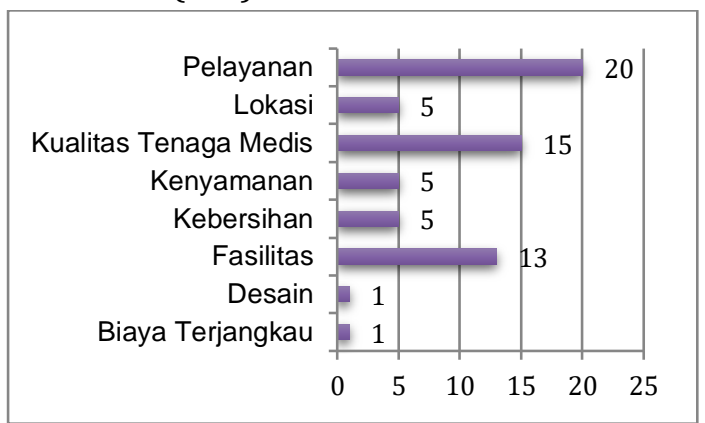

Gambar 3. Analisis distribusi kategori kelebihan RSIA yang dikunjungi pasien (sumber: analisis penulis, 2020)

\section{Pengunjung Umum}

Pada analisis open coding persepsi pengunjung umum terhadap kelebihan RSIA yang dikunjungi ditemukan 12 kategori, yaitu: biaya terjangkau, daya tarik, desain, fasilitas, fleksibilitas, ideologi, keamanan, kebersihan, kenyamanan, kualitas tenaga medis, lokasi, dan pelayanan. (Tabel 5)

Tabel 5. Hasil open coding persepsi pengunjung umum terhadap kelebihan RSIA yang dikunjungi.

\begin{tabular}{|c|c|c|}
\hline No & Kata Kunci & Kategori \\
\hline 1 & Biaya terjangkau & $\begin{array}{l}\text { Biaya } \\
\text { Terjangkau }\end{array}$ \\
\hline 2 & $\begin{array}{l}\text { Menarik } \\
\text { Ada pick-up point gojek } \\
\text { Kuliner variatif }\end{array}$ & Daya Tarik \\
\hline 3 & $\begin{array}{l}\text { Bagus } \\
\text { Baik } \\
\text { Baru } \\
\text { Interior baik } \\
\text { Interior bersih } \\
\text { Interior jelas } \\
\text { Interior rapi } \\
\text { Parkir baik } \\
\text { Parkir luas } \\
\text { Parkir mudah } \\
\text { Rawat inap baik } \\
\text { Ruang tunggu baik } \\
\text { Ruang perawatan baik } \\
\text { Spesifik }\end{array}$ & Desain \\
\hline 4 & $\begin{array}{l}\text { Ada playground anak } \\
\text { Asuransi } \\
\text { Fasilitas bagus } \\
\text { Fasilitas baik } \\
\text { Fasilitas lengkap } \\
\text { Fasilitas memadai } \\
\text { Lengkap }\end{array}$ & Fasilitas \\
\hline 5 & $\begin{array}{l}24 \text { jam } \\
\text { Waktu praktik banyak }\end{array}$ & Fleksibilitas \\
\hline
\end{tabular}




\begin{tabular}{|c|c|c|}
\hline 6 & Agamis & Ideologi \\
\hline 7 & $\begin{array}{l}\text { Penjagaan ketat } \\
\text { Terpercaya }\end{array}$ & Keamanan \\
\hline 8 & Bersih & Kebersihan \\
\hline 9 & $\begin{array}{l}\text { Homey } \\
\text { Nyaman } \\
\text { Pengunjung sedikit } \\
\text { Prioritaskan ibu \& anak } \\
\text { Rapi } \\
\text { Tenang } \\
\text { Tidak membedakan } \\
\text { pasien } \\
\text { Udara nyaman }\end{array}$ & Kenyamanan \\
\hline 10 & $\begin{array}{l}\text { Kualitas dokter } \\
\text { Pilihan dokter } \\
\text { Tenaga medis baik } \\
\text { Tenaga medis ramah } \\
\end{array}$ & $\begin{array}{l}\text { Kualitas } \\
\text { Tenaga Medis }\end{array}$ \\
\hline 11 & $\begin{array}{l}\text { Akses mudah } \\
\text { Dekat } \\
\text { Dekat dengan fasilitas } \\
\text { umum } \\
\text { Dekat rumah } \\
\text { Lokasi strategis } \\
\text { Strategis } \\
\end{array}$ & Lokasi \\
\hline 12 & $\begin{array}{l}\text { Pelayanan baik } \\
\text { Pelayanan cepat } \\
\text { Pelayanan lengkap } \\
\text { Pelayanan memuaskan } \\
\text { Pelayanan profesional } \\
\text { Pelayanan ramah } \\
\text { Pelayanan responsif } \\
\text { Pelayanan tanggap } \\
\text { Ramah }\end{array}$ & Pelayanan \\
\hline
\end{tabular}

Sumber: analisis penulis, 2020

Hasil analisis distribusi (Gambar 4) menunjukkan bahwa kelebihan RSIA yang dikunjungi menurut pengunjung umum cenderung karena aspek pelayanan sebesar 37 (20\%), kemudian disusul oleh kualitas tenaga medis sebesar 27 (15\%), lalu kebersihan sebesar 26 (14\%), kenyamanan sebesar 24 (13\%), fasilitas sebesar 23 (13\%), lokasi sebesar 18 (10\%), desain sebesar 16 (9\%), daya tarik sebesar 3 (2\%), keamanan, fleksibilitas, dan biaya terjangkau yang masing-masing sebesar 2 (1\%), dan terakhir adalah ideologi sebesar 1 (1\%).

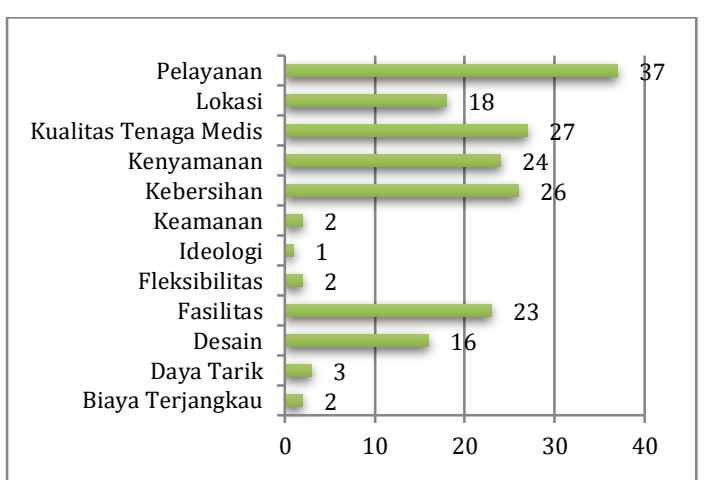

Gambar 4. Analisis distribusi kategori kelebihan RSIA yang dikunjungi pengunjung umum (sumber: analisis penulis, 2020)

\section{Perbedaan Persepsi Pasien dan Pengunjung Umum}

Persepsi tertinggi pasien maupun pengunjung umum terhadap kelebihan Rumah Sakit Ibu dan Anak (RSIA) yang dikunjungi adalah dari aspek non arsitektural, dengan prosentase masingmasing sebesar 74\% (pasien) dan 51\% (pengunjung umum). Kelebihan RSIA yang dikunjungi dalam aspek non arsitektural antara lain; biaya terjangkau, fasilitas, fleksibilitas, ideologi, kualitas tenaga medis, dan pelayanan. Kemudian, sebesar $24 \%$ (pasien) dan 38\% (pengunjung umum) memilih RSIA berdasarkan aspek non-visual arsitekturnya, yaitu keamanan, kebersihan, kenyamanan, dan lokasi. Sebesar 2\% (pasien) dan 11\% (pengunjung umum) memilih RSIA berdasarkan aspek visual arsitektural, yaitu desain dan daya tariknya. (Tabel 6)

Hal ini dikarenakan oleh hal pertama yang dilihat dan dirasakan pengguna, pasien maupun pengunjung umum selaras dengan tujuan memilih RSIA, yaitu fasilitas kesehatannya. Maka dari itu, kelebihan yang dilihat dan dirasakan oleh pengguna adalah pelayanan dari RSIA tersebut. 
Tabel 6. Persepsi pasien dan pengguna umum terhadap kelebihan RSIA yang dikunjungi.

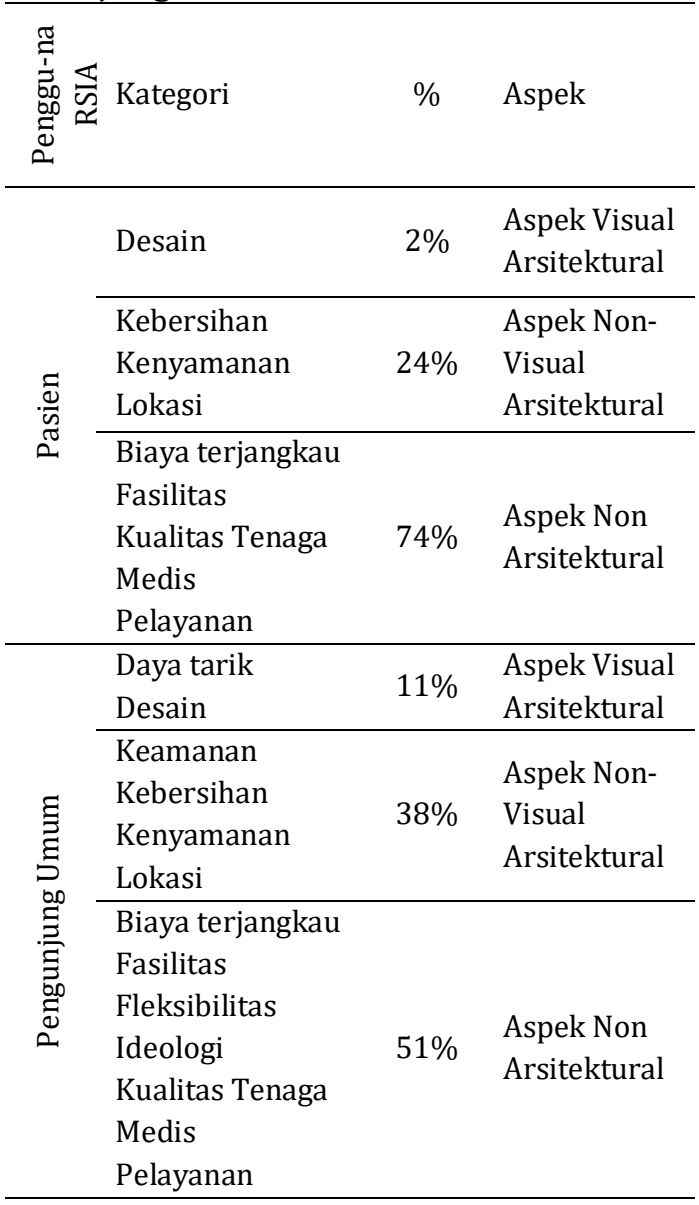

Sumber: hasil analisis, 2020

Persepsi utama pengguna (pasien dan pengunjung umum) terhadap kelebihan RSIA serupa. Mayoritas pengguna melihat dan merasa pelayanan yang baik sebagai hal terpenting dalam RSIA. Hal-hal yang termasuk dalam pelayanan antara lain adalah keterampilan, profesionalitas, dan komunikasi staf rumah sakit yang baik, seperti bagaimana interaksi sosial antar pasien dan staf, mulai staf medis sampai non medis, dapat membuat pasien merasa nyaman. Pelayanan yang baik adalah salah satu faktor yang dapat meningkatkan kepuasan, kenyamanan, dan kepercayaan pengguna RSIA tersebut (Noor, 2018).

\section{Preferensi Pengguna Terhadap Kekurangan RSIA \\ Pasien}

Pada analisis open coding persepsi pasien terhadap kekurangan RSIA yang dikunjungi ditemukan 10 kategori, yaitu: biaya tinggi, desain kurang baik, fasilitas kurang memadai, kenyamanan kurang baik, kurang area hijau, lama mengantre, lokasi kurang baik, parkir kurang memadai, pelayanan kurang baik, dan terlalu ramai. (Tabel 7)

Tabel 7. Hasil open coding persepsi pasien terhadap kekurangan RSIA yang dikunjungi

\begin{tabular}{|c|c|c|}
\hline No & Kata Kunci & Kategori \\
\hline 1 & Biaya tinggi & Biaya Tinggi \\
\hline 2 & $\begin{array}{l}\text { Interior kurang } \\
\text { Luas bangunan } \\
\text { kurang }\end{array}$ & $\begin{array}{l}\text { Desain Kurang } \\
\text { Baik }\end{array}$ \\
\hline 3 & $\begin{array}{l}\text { Asuransi } \\
\text { Fasilitas kurang } \\
\text { Fasilitas kurang } \\
\text { memadai } \\
\text { Rawat inap sempit } \\
\text { Rawat inap terbatas }\end{array}$ & $\begin{array}{l}\text { Fasilitas Kurang } \\
\text { Memadai }\end{array}$ \\
\hline 4 & $\begin{array}{l}\text { Kurang nyaman } \\
\text { Sepi }\end{array}$ & $\begin{array}{l}\text { Kenyamanan } \\
\text { Kurang Baik }\end{array}$ \\
\hline 5 & Kurang area hijau & $\begin{array}{l}\text { Kurang Area } \\
\text { Hijau }\end{array}$ \\
\hline 6 & $\begin{array}{l}\text { Antre lama } \\
\text { Antre panjang }\end{array}$ & Lama Mengantre \\
\hline 7 & $\begin{array}{l}\text { Lokasi jauh } \\
\text { Lokasi kurang baik }\end{array}$ & $\begin{array}{l}\text { Lokasi Kurang } \\
\text { Baik }\end{array}$ \\
\hline 8 & Parkir kurang & $\begin{array}{l}\text { Parkir Kurang } \\
\text { Memadai }\end{array}$ \\
\hline 9 & $\begin{array}{l}\text { Pelayanan kurang } \\
\text { baik } \\
\text { Variasi konsumsi } \\
\text { kurang }\end{array}$ & $\begin{array}{l}\text { Pelayanan } \\
\text { Kurang Memadai }\end{array}$ \\
\hline 10 & $\begin{array}{l}\text { Pasien banyak } \\
\text { Terlalu ramai }\end{array}$ & Terlalu Ramai \\
\hline
\end{tabular}

Sumber: analisis penulis,2020

Hasil analisis distribusi (Gambar 5) menunjukkan bahwa kekurangan RSIA yang dikunjungi menurut pasien cenderung karena parkir kurang memadai sebesar 9 (22\%), kemudian disusul oleh fasilitas kurang memadai sebesar 8 (20\%), lalu pelayanan kurang baik dan lama mengantre yang masing-masing sebesar 5 (12\%), terlalu ramai dan biaya tinggi yang masing-masing sebesar 3 (7\%), dan terakhir ada lokasi kurang baik, kurang 
area hijau, kenyamanan kurang baik, dan desain kurang baik yang masing-masing sebesar 2 (5\%).

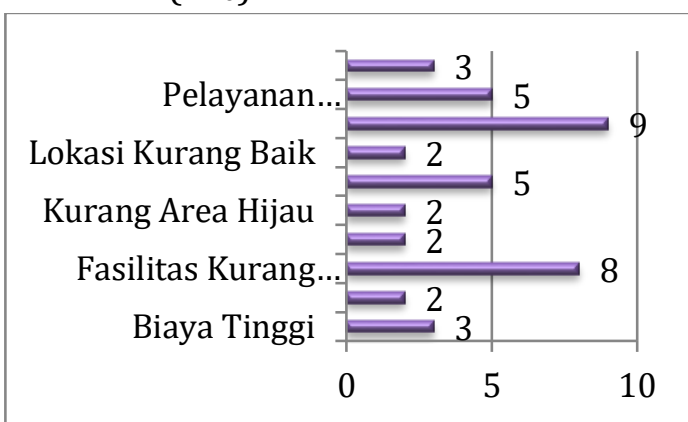

Gambar 5. Analisis distribusi kategori kekurangan RSIA yang dikunjungi pasien (sumber: hasil analisis,2020)

\section{Pengunjung Umum}

Pada analisis open coding persepsi pengunjung umum terhadap kekurangan RSIA yang dikunjungi ditemukan 10 kategori, yaitu: aksesibilitas kurang baik, biaya tinggi, desain kurang baik, fasilitas kurang memadai, lama mengantre, lokasi kurang baik, parkir kurang memadai, pelayanan kurang baik, tenaga medis kurang baik, dan terlalu ramai. (Tabel 8)

Tabel 8. Hasil open coding persepsi pengunjung umum terhadap kekurangan RSIA yang dikunjungi

\begin{tabular}{|c|c|c|}
\hline No & Kata Kunci & Kategori \\
\hline 1 & $\begin{array}{l}\text { Akses kurang baik } \\
\text { Akses masuk kurang } \\
\text { jelas }\end{array}$ & $\begin{array}{l}\text { Aksesibilitas } \\
\text { Kurang Baik }\end{array}$ \\
\hline 2 & $\begin{array}{l}\text { Biaya tinggi } \\
\text { Mahal }\end{array}$ & Biaya Tinggi \\
\hline 3 & $\begin{array}{l}\text { Area lobby kurang luas } \\
\text { Bangunan kurang luas } \\
\text { Desain kurang } \\
\text { menunjukkan } \\
\text { Jarak antar bangunan } \\
\text { jauh } \\
\text { Keamanan kurang } \\
\text { Kuno } \\
\text { Kurang luas } \\
\text { Kurang menarik } \\
\text { Lokasi kurang } \\
\text { memadai } \\
\text { Mushola kecil } \\
\text { Penanda kurang } \\
\text { Pencahayaan alami } \\
\text { kurang } \\
\text { Ruang bermain anak } \\
\text { kurang } \\
\text { Ruang gerak terbatas } \\
\text { Ruang inap kurang } \\
\text { nyaman }\end{array}$ & $\begin{array}{l}\text { Desain Kurang } \\
\text { Baik }\end{array}$ \\
\hline
\end{tabular}

\begin{tabular}{|c|c|c|}
\hline & $\begin{array}{l}\text { Ruang udara kurang } \\
\text { Ruang tunggu kurang } \\
\text { Sempit } \\
\text { Sirkulasi kurang jelas } \\
\text { Tidak ada lahan parkir } \\
\text { khusus } \\
\text { Tidak ada view } \\
\text { Tidak ramah anak }\end{array}$ & \\
\hline 4 & $\begin{array}{l}\text { Alat medis kurang } \\
\text { lengkap } \\
\text { Fasilitas kurang } \\
\text { memadai } \\
\text { Kantin kurang lengkap } \\
\text { Lift kurang } \\
\text { Terbatas } \\
\text { Tidak ada kantin } \\
\text { Tidak bisa memakai } \\
\text { asuransi }\end{array}$ & $\begin{array}{l}\text { Fasilitas } \\
\text { Kurang } \\
\text { Memadai }\end{array}$ \\
\hline 5 & $\begin{array}{l}\text { Antrian panjang } \\
\text { Lama menunggu obat }\end{array}$ & $\begin{array}{l}\text { Lama } \\
\text { Mengantre }\end{array}$ \\
\hline 6 & Jauh dari rumah & $\begin{array}{l}\text { Lokasi Kurang } \\
\text { Baik }\end{array}$ \\
\hline 7 & $\begin{array}{l}\text { Parkir kurang } \\
\text { Parkir kurang } \\
\text { memadai } \\
\text { Parkir kurang nyaman } \\
\text { Parkir pada bahu jalan } \\
\text { Parkir sempit } \\
\text { Parkir terbatas } \\
\text { Parkir tidak teratur }\end{array}$ & $\begin{array}{l}\text { Parkir Kurang } \\
\text { Memadai }\end{array}$ \\
\hline 8 & $\begin{array}{l}\text { Pelayanan buruk } \\
\text { Pelayanan kurang baik } \\
\text { Pelayanan lama }\end{array}$ & $\begin{array}{l}\text { Pelayanan } \\
\text { Kurang Baik }\end{array}$ \\
\hline 9 & $\begin{array}{l}\text { Pilihan dokter kurang } \\
\text { Tenaga medis kurang }\end{array}$ & $\begin{array}{l}\text { Tenaga Medis } \\
\text { Kurang Baik }\end{array}$ \\
\hline 10 & Terlalu ramai & Terlalu Ramai \\
\hline
\end{tabular}

Sumber: hasil analisis 2020

Hasil analisis distribusi (Gambar 6) menunjukkan bahwa kekurangan RSIA yang dikunjungi menurut pengunjung umum cenderung karena parkir kurang memadai sebesar 31 (34\%), kemudian disusul oleh desain kurang baik sebesar 26 (28\%), lalu fasilitas kurang memadai sebesar 8 (9\%), pelayanan kurang baik sebesar 6 (7\%), terlalu ramai dan biaya tinggi yang masing-masing sebesar 5 (5\%), lama mengantre sebesar $4(4 \%)$, tenaga medis kurang baik sebesar 3 (3\%), dan terakhir adalah lokasi dan aksesibilitas kurang baik yang masingmasing sebesar $2(2 \%)$.

Preferensi, Persepsi, dan Harapan Pengguna Terhadap Rumah Sakit Ibu dan Anak (RSIA) 


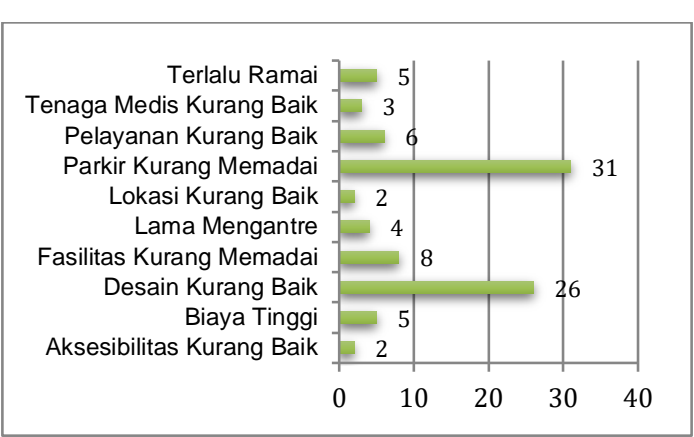

Gambar 6. Analisis distribusi kategori kekurangan RSIA yang dikunjungi pengunjung umum (hail analisis 2020)

\section{Perbedaan Persepsi Pasien dan Pengunjung Umum}

Persepsi tertinggi pasien terhadap kekurangan Rumah Sakit Ibu dan Anak (RSIA) yang dikunjungi adalah dari aspek non-arsitektural, dengan prosentase 58\%, yaitu biaya tinggi, fasilitas kurang memadai, lama mengantre, pelayanan kurang baik, dan terlalu ramai. Berbeda dengan persepsi pengunjung umum mengenai kekurangan RSIA yang dikunjungi. Karena yang tertinggi adalah pada aspek visual arsitektur, dengan prosentase sebesar 64\%, yaitu aksesibilitas kurang baik, desain kurang baik, dan parkir kurang memadai. Kemudian, aspek non-visual arsitektural berada pada tingkat terendah bagi pasien maupun pengunjung umum dengan prosentase masing-masing sebesar $10 \%$ dan $2 \%$, yaitu kenyamanan dan lokasi yang kurang baik. (Tabel 9)

Perbedaan persepsi ini dikarenakan adanya perbedaan kepentingan antara pasien dan pengunjung umum. Maka dari itu, pasien lebih mementingkan aspek nonarsitekturalnya. Ketika keadaan pada lapangan tidak sesuai dengan persepsi pasien, maka hal tersebut menjadi sebuah kekurangan. Sedangkan untuk pengunjung umum, yang tidak terlibat langsung dengan pemeriksaan kesehatan akan melihat perspektif yang berbeda. Maka, persepsi pertama pengunjung umum adalah hal yang dapat dilihat langsung dan berhubungan dengan kegiatan pengunjung umum yang mayoritas adalah pengantar pasien, yaitu aspek visual arsitekturnya.
Tabel 9. Persepsi pasien dan pengguna umum terhadap kekurangan RSIA yang dikunjungi

\begin{tabular}{|c|c|c|c|}
\hline 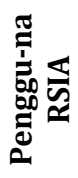 & Kategori & $\%$ & Aspek \\
\hline \multirow{3}{*}{ 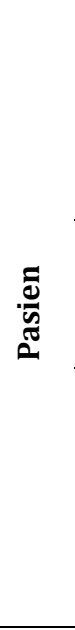 } & $\begin{array}{l}\text { Desain kurang } \\
\text { baik } \\
\text { Kurang area } \\
\text { hijau } \\
\text { Parkir kurang } \\
\text { memadai }\end{array}$ & $32 \%$ & $\begin{array}{l}\text { Aspek Visual } \\
\text { Arsitektural }\end{array}$ \\
\hline & $\begin{array}{l}\text { Kenyamanan } \\
\text { kurang baik } \\
\text { Lokasi kurang } \\
\text { baik } \\
\end{array}$ & $10 \%$ & $\begin{array}{l}\text { Aspek Non- } \\
\text { Visual } \\
\text { Arsitektural }\end{array}$ \\
\hline & $\begin{array}{l}\text { Biaya tinggi } \\
\text { Fasilitas kurang } \\
\text { memadai } \\
\text { Lama mengantre } \\
\text { Pelayanan } \\
\text { kurang baik } \\
\text { Terlalu ramai }\end{array}$ & $58 \%$ & $\begin{array}{l}\text { Aspek Non- } \\
\text { Arsitektural }\end{array}$ \\
\hline \multirow{3}{*}{ 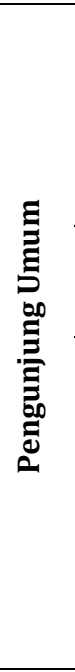 } & $\begin{array}{l}\text { Aksesibilitas } \\
\text { kurang baik } \\
\text { Desain kurang } \\
\text { baik } \\
\text { Parkir kurang } \\
\text { memadai } \\
\end{array}$ & $64 \%$ & $\begin{array}{l}\text { Aspek Visual } \\
\text { Arsitektural }\end{array}$ \\
\hline & $\begin{array}{l}\text { Lokasi kurang } \\
\text { baik }\end{array}$ & $2 \%$ & $\begin{array}{l}\text { Aspek Non- } \\
\text { Visual } \\
\text { Arsitektural }\end{array}$ \\
\hline & $\begin{array}{l}\text { Biaya tinggi } \\
\text { Fasilitas kurang } \\
\text { memadai } \\
\text { Lama mengantre } \\
\text { Pelayanan } \\
\text { kurang baik } \\
\text { Tenaga medis } \\
\text { kurang baik } \\
\text { Terlalu ramai }\end{array}$ & $34 \%$ & $\begin{array}{l}\text { Aspek Non } \\
\text { Arsitektural }\end{array}$ \\
\hline
\end{tabular}

Sumber: hasil analisis 2020

Namun, terlepas dari prosentase aspek tersebut, persepsi pasien dan pengunjung umum terhadap kekurangan RSIA serupa, yaitu parkir yang kurang memadai. Hal ini dikarenakan mayoritas pengguna mengunjungi RSIA dengan menggunakan kendaraan pribadi. Maka, hal pertama yang dilakukan ketika sampai adalah mencari tempat parkir. Ketika persepsi akan lahan parkir bagi pengguna tidak sesuai, maka hal ini menjadi sebuah kekurangan. Kurangnya lahan parkir bisa terjadi karena lahan yang sebelumnya ditujukan untuk pengguna digunakan untuk parkir kendaraan staf rumah sakit 
(Hirtanto et al., 2006). Tersedianya lahan parkir yang cukup kini merupakan hal yang penting dalam perencanaan RSIA.

\section{Harapan Pengguna Terhadap RSIA}

\section{Pasien}

Pada analisis open coding harapan pasien terhadap RSIA ditemukan 10 kategori, yaitu: area hijau, biaya terjangkau, desain ramah anak, fasilitas baik, kebersihan terjaga, kenyamanan ruang, lokasi baik, parkir memadai, pelayanan baik, dan tenaga medis baik. (Tabel 10)

Tabel 10. Hasil open coding harapan pasien terhadap RSIA

\begin{tabular}{|c|c|c|}
\hline No & Kata Kunci & Kategori \\
\hline 1 & Area hijau & Area Hijau \\
\hline 2 & Biaya terjangkau & $\begin{array}{l}\text { Biaya } \\
\text { Terjangkau }\end{array}$ \\
\hline 3 & $\begin{array}{l}\text { Ada ruang bermain } \\
\text { anak } \\
\text { Desain ramah anak } \\
\text { Fasilitas ramah anak } \\
\text { Ramah anak }\end{array}$ & $\begin{array}{l}\text { Desain Ramah } \\
\text { Anak }\end{array}$ \\
\hline 4 & $\begin{array}{l}\text { Ada fasilitas } \\
\text { tambahan } \\
\text { Fasilitas baik } \\
\text { Fasilitas lengkap } \\
\text { Fasilitas tambahan } \\
\text { lengkap } \\
\text { Variasi konsumsi }\end{array}$ & Fasilitas Baik \\
\hline 5 & $\begin{array}{l}\text { Bersih } \\
\text { Kebersihan terjaga }\end{array}$ & $\begin{array}{l}\text { Kebersihan } \\
\text { Terjaga }\end{array}$ \\
\hline 6 & $\begin{array}{l}\text { Ada media hiburan } \\
\text { Homey } \\
\text { Ideal } \\
\text { Kapasitas memadai } \\
\text { Laktasi nyaman } \\
\text { Luas } \\
\text { Nyaman } \\
\text { Playground yang } \\
\text { aman } \\
\text { Ruang tunggu cukup } \\
\text { Ruang tunggu } \\
\text { nyaman } \\
\text { Sirkulasi nyaman }\end{array}$ & $\begin{array}{l}\text { Kenyamanan } \\
\text { Ruang }\end{array}$ \\
\hline 7 & $\begin{array}{l}\text { Akses mudah } \\
\text { Dekat } \\
\text { Lokasi baik } \\
\text { Lokasi strategis }\end{array}$ & Lokasi Baik \\
\hline 8 & $\begin{array}{l}\text { Parkir memadai } \\
\text { Parkir mudah }\end{array}$ & Parkir Memadai \\
\hline 9 & $\begin{array}{l}\text { Alat medis lengkap } \\
\text { Asuransi } \\
\text { Durasi menunggu } \\
\text { baik } \\
\text { Farmasi lengkap } \\
\text { Mampu adaptasi } \\
\text { dengan pandemi } \\
\text { Pelayanan } \\
\text { Pelayanan baik } \\
\text { Pelayanan cepat }\end{array}$ & Pelayanan Baik \\
\hline
\end{tabular}

\begin{tabular}{lll}
\hline & Pelayanan medis & \\
& lengkap \\
& Pelayanan mudah & \\
& Pelayanan ramah & \\
& Pelayanan teknologi & \\
& Waktu pelayanan & \\
baik & & \\
\hline & Dokter & \\
berpengalaman & Tenaga Medis \\
& Tenaga medis baik & Baik \\
& Tenaga medis ramah & \\
\hline
\end{tabular}

Sumber: hasil analisis 2020

Hasil analisis distribusi (Gambar 7) menunjukkan bahwa harapan pasien terhadap RSIA cenderung karena fasilitas baik sebesar 20 (24\%), kemudian disusul oleh pelayanan baik sebesar 17 (20\%), lalu kenyamanan ruang sebesar 14 (17\%), desain ramah anak sebesar 8 (10\%), tenaga medis baik sebesar 6 (7\%), parkir memadai, lokasi baik, kebersihan terjaga, dan area hijau yang masing-masing sebesar 4 (5\%), dan terakhir adalah biaya terjangkau $2(2 \%)$.

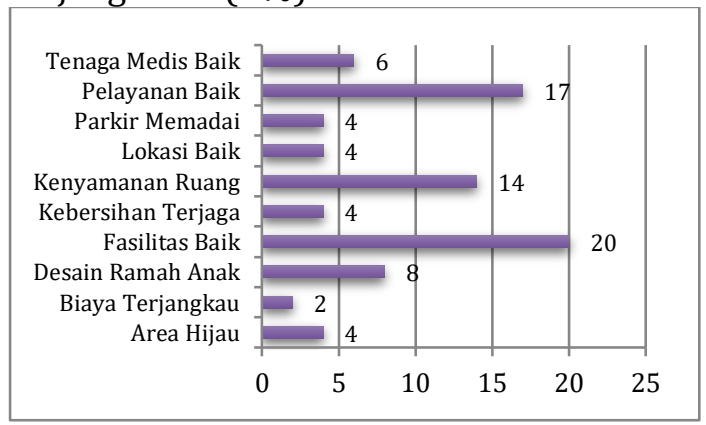

Gambar 7. Analisis distribusi kategori harapan pasien terhadap RSIA. (sumber: hasil analisis, 2020)

\section{Pengunjung Umum}

Pada analisis open coding harapan pengunjung umum terhadap RSIA ditemukan 14 kategori, yaitu: aksesibilitas baik, area hijau, biaya terjangkau, desain baik, fasilitas baik, kebersihan terjaga, kenyamanan ruang, lokasi baik, parkir memadai, pelayanan baik, prioritaskan ibu \& anak, reputasi baik, sesuai standar pemerintah, dan tenaga medis baik. (Tabel 11)

Preferensi, Persepsi, dan Harapan Pengguna Terhadap Rumah Sakit Ibu dan Anak (RSIA) 
Tabel 11. Hasil open coding harapan pengunjung umum terhadap RSIA

\begin{tabular}{|c|c|c|}
\hline No & Kata Kunci & Kategori \\
\hline 1 & $\begin{array}{l}\text { Akses jelas } \\
\text { Akses mudah } \\
\text { Akses mudah dicapai } \\
\text { Terjangkau kendaraan } \\
\text { umum }\end{array}$ & $\begin{array}{l}\text { Aksesibilitas } \\
\text { Baik }\end{array}$ \\
\hline 2 & $\begin{array}{l}\text { Ada area hijau } \\
\text { Ada taman }\end{array}$ & Area Hijau \\
\hline 3 & Biaya terjangkau & $\begin{array}{l}\text { Biaya } \\
\text { Terjangkau }\end{array}$ \\
\hline 4 & $\begin{array}{l}\text { Adanya playground } \\
\text { Akses UGD luas } \\
\text { Bangunan baik } \\
\text { Banyak ruang terbuka } \\
\text { Keamanan terjamin } \\
\text { Kemudahan sirkulasi } \\
\text { Konfigurasi ruang baik } \\
\text { Lingkungan baik } \\
\text { Luas } \\
\text { Menarik } \\
\text { Modern } \\
\text { Penanda ruang jelas } \\
\text { Pencahayaan cukup } \\
\text { Ramah anak } \\
\text { Ramah pejalan kaki } \\
\text { Rawat inap baik } \\
\text { Ruang tunggu baik } \\
\text { Ruang tunggu cukup } \\
\text { Ruang tunggu luas } \\
\text { Ruang tunggu ramah } \\
\text { balita } \\
\text { Ruang tunggu tidak } \\
\text { membosankan } \\
\text { Sirkulasi jelas } \\
\text { Sirkulasi udara cukup } \\
\text { Suasana interior nyaman } \\
\text { View baik }\end{array}$ & Desain Baik \\
\hline 5 & $\begin{array}{l}\text { Ada fasilitas tambahan } \\
\text { Ada fasilitas restoran } \\
\text { Alat medis baik } \\
\text { Alat medis lengkap } \\
\text { Asuransi } \\
\text { Canggih } \\
\text { Fasilitas baik } \\
\text { Fasilitas lengkap } \\
\text { Fasilitas lengkap untuk } \\
\text { ibu \& anak } \\
\text { Fasilitas memadai } \\
\text { Fasilitas menyenangkan } \\
\text { Fasilitas prasarana baik } \\
\text { Informasi antrian dari } \\
\text { aplikasi } \\
\text { Infrastruktur lengkap } \\
\text { Lift sesuai kapasitas } \\
\text { Obat BPJS lengkap } \\
\text { Teknologi untuk } \\
\text { mengantre }\end{array}$ & Fasilitas Baik \\
\hline 6 & $\begin{array}{l}\text { Bersih } \\
\text { Lingkungan bersih }\end{array}$ & $\begin{array}{l}\text { Kebersihan } \\
\text { Terjaga }\end{array}$ \\
\hline 7 & $\begin{array}{l}\text { Homey } \\
\text { Kantin pengunjung } \\
\text { nyaman }\end{array}$ & $\begin{array}{l}\text { Kenyamanan } \\
\text { Ruang }\end{array}$ \\
\hline
\end{tabular}

\begin{tabular}{|c|c|c|}
\hline & $\begin{array}{l}\text { Minim lorong } \\
\text { Nyaman } \\
\text { Ruang tunggu nyaman } \\
\text { Suasana hangat } \\
\text { Tenang }\end{array}$ & \\
\hline 8 & $\begin{array}{l}\text { Dekat } \\
\text { Dekat rumah } \\
\text { Lokasi baik } \\
\text { Lokasi strategis } \\
\text { Strategis } \\
\end{array}$ & Lokasi Baik \\
\hline 9 & $\begin{array}{l}\text { Parkir baik } \\
\text { Parkir cukup } \\
\text { Parkir luas } \\
\text { Parkir memadai } \\
\text { Parkir nyaman } \\
\end{array}$ & $\begin{array}{l}\text { Parkir } \\
\text { Memadai }\end{array}$ \\
\hline 10 & $\begin{array}{l}\text { Administrasi mudah } \\
\text { Memenuhi kebutuhan } \\
\text { pasien } \\
\text { Mengikuti protokol covid } \\
\text { Menjaga mental pasien } \\
\text { Obat diantar ke rumah } \\
\text { Pelayanan baik } \\
\text { Pelayanan cepat } \\
\text { Pelayanan jujur } \\
\text { Pelayanan lengkap } \\
\text { Pelayanan memuaskan } \\
\text { Pelayanan profesional } \\
\text { Pelayanan ramah } \\
\text { Prioritas urgensi } \\
\text { Sistem administrasi baik } \\
\text { Tidak ada rujukan } \\
\text { Transparan }\end{array}$ & $\begin{array}{l}\text { Pelayanan } \\
\text { Baik }\end{array}$ \\
\hline 11 & $\begin{array}{l}\text { Mengayomi ibu \& anak } \\
\text { Nyaman untuk ibu \& } \\
\text { anak } \\
\text { Prioritaskan ibu \& anak } \\
\text { Ramah ibu \& anak }\end{array}$ & $\begin{array}{l}\text { Prioritaskan } \\
\text { Ibu \& Anak }\end{array}$ \\
\hline 12 & Reputasi baik & $\begin{array}{l}\text { Reputasi } \\
\text { Baik }\end{array}$ \\
\hline 13 & $\begin{array}{l}\text { Sesuai standar } \\
\text { pemerintah }\end{array}$ & $\begin{array}{l}\text { Sesuai } \\
\text { Standar } \\
\text { Pemerintah }\end{array}$ \\
\hline 14 & $\begin{array}{l}\text { Dokter berkualitas } \\
\text { Dokter ramah } \\
\text { Memberi edukasi } \\
\text { Pilihan dokter } \\
\text { berkualitas } \\
\text { Tenaga medis baik } \\
\text { Tenaga medis profesional } \\
\text { Tenaga medis ramah }\end{array}$ & $\begin{array}{l}\text { Tenaga } \\
\text { Medis Baik }\end{array}$ \\
\hline
\end{tabular}

Sumber: hasil analisis, 2020

Hasil analisis distribusi (Gambar 8) menunjukkan bahwa harapan pengunjung umum terhadap RSIA cenderung karena pelayanan baik sebesar 50 (21\%), kemudian disusul oleh fasilitas baik sebesar 43 (18\%), lalu desain baik sebesar 25 (11\%), kebersihan terjaga sebesar 24 (10\%), kenyamanan ruang sebesar 22 (9\%), tenaga medis berkualitas sebesar 21 
(9\%), biaya terjangkau sebesar 15 (6\%), parkir memadai sebesar $10 \quad(4 \%)$, prioritaskan ibu \& anak dan lokasi baik yang masing-masing sebesar 7 (3\%), aksesibilitas baik sebesar 5 (2\%), area hijau sebesar 4 (2\%), dan terakhir adalah sesuai standar pemerintah dan reputasi baik yang masing-masing sebesar $1(0 \%)$.

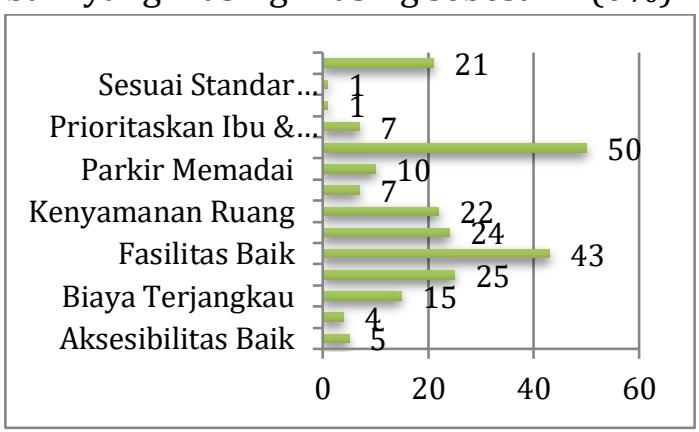

Gambar 8. Analisis distribusi kategori harapan pengunjung umum terhadap RSIA (hasil analisis, 2020)

\section{Perbedaan Harapan Pasien dan Pengunjung Umum}

Harapan tertinggi pasien maupun pengunjung umum terhadap Rumah Sakit Ibu dan Anak (RSIA) adalah dari aspek non arsitektural, dengan prosentase masingmasing sebesar 61\% (pasien) dan 59\% (pengunjung umum). Harapan terhadap RSIA dalam aspek non arsitektural antara lain; biaya terjangkau, fasilitas baik, pelayanan baik, prioritaskan ibu \& anak, reputasi baik, sesuai standar pemerintah, dan tenaga medis baik. Kemudian, sebesar $27 \%$ (pasien) dan 22\% (pengunjung umum) memiliki harapan terhadap RSIA berdasarkan aspek non-visual arsitekturnya, yaitu kebersihan terjaga, kenyamanan ruang, dan lokasi baik. Sebesar $12 \%$ (pasien) dan 19\% (pengunjung umum) mengharapkan RSIA ideal berdasarkan aspek visual arsitektural, yaitu aksesibilitas baik, area hijau, desain ramah anak, dan parkir memadai. (Tabel 12)

Hal ini selaras dengan tujuan utama pengguna, baik pasien maupun pengunjung umum, yaitu menggunakan fasilitas kesehatannya. Maka dari itu, harapan utama pengguna RSIA adalah dalam aspek non arsitekturalnya, antara lain; pelayanan, fasilitas, kualitas tenaga medis, dan lain sebagainya.

Tabel 12. Harapan pasien dan pengguna umum terhadap RSIA

\begin{tabular}{|c|c|c|c|}
\hline 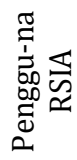 & Kategori & $\%$ & Aspek \\
\hline \multirow{3}{*}{ 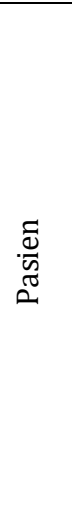 } & $\begin{array}{l}\text { Area hijau } \\
\text { Desain ramah } \\
\text { anak } \\
\text { Parkir memadai }\end{array}$ & $12 \%$ & $\begin{array}{l}\text { Aspek Visual } \\
\text { Arsitektural }\end{array}$ \\
\hline & $\begin{array}{l}\text { Kebersihan } \\
\text { terjaga } \\
\text { Kenyamanan } \\
\text { ruang } \\
\text { Lokasi baik }\end{array}$ & $27 \%$ & $\begin{array}{l}\text { Aspek Non- } \\
\text { Visual } \\
\text { Arsitektural }\end{array}$ \\
\hline & $\begin{array}{l}\text { Biaya terjangkau } \\
\text { Fasilitas baik } \\
\text { Pelayanan baik } \\
\text { Tenaga medis } \\
\text { baik }\end{array}$ & $61 \%$ & $\begin{array}{l}\text { Aspek Non } \\
\text { Arsitektural }\end{array}$ \\
\hline \multirow{3}{*}{$\begin{array}{l}\Xi \\
\Xi \\
\Xi \\
\Xi \\
0 \\
\Xi \\
\Xi \\
\Xi \\
\Xi \\
0 \\
0 \\
0\end{array}$} & $\begin{array}{l}\text { Aksesibilitas baik } \\
\text { Area hijau } \\
\text { Desain baik } \\
\text { Parkir memadai }\end{array}$ & $19 \%$ & $\begin{array}{l}\text { Aspek Visual } \\
\text { Arsitektural }\end{array}$ \\
\hline & $\begin{array}{l}\text { Kebersihan } \\
\text { terjaga } \\
\text { Kenyamanan } \\
\text { ruang } \\
\text { Lokasi baik } \\
\end{array}$ & $22 \%$ & $\begin{array}{l}\text { Aspek Non- } \\
\text { Visual } \\
\text { Arsitektural }\end{array}$ \\
\hline & $\begin{array}{l}\text { Biaya terjangkau } \\
\text { Fasilitas baik } \\
\text { Pelayanan baik } \\
\text { Prioritaskan ibu } \\
\text { \& anak } \\
\text { Reputasi baik } \\
\text { Sesuai standar } \\
\text { pemerintah } \\
\text { Tenaga medis } \\
\text { baik }\end{array}$ & $59 \%$ & $\begin{array}{l}\text { Aspek Non } \\
\text { Arsitektural }\end{array}$ \\
\hline
\end{tabular}

Sumber: hasil analisis, 2020

Terdapat perbedaan harapan antara pasien dan pengunjung, namun masih di dalam 1 aspek, yaitu aspek nonarsitektural. Harapan utama pasien terhadap RSIA adalah fasilitas yang baik. Fasilitas yang dimaksud pada penelitian ini adalah fasilitas kesehatan yang ada di dalam RSIA, di mana sudah diatur dalam Pedoman Teknis Sarana dan Prasarana Bangunan Rumah Sakit yang disusun oleh 
pemerintah. Selain itu, adanya fasilitas tambahan yang menunjang kegiatan utama seperti spa ibu, spa bayi, dan lain sebagainya pun termasuk dalam kategori ini. Sedangkan bagi pengunjung umum yang tidak berhubungan langsung dengan pemeriksaan kesehatan, memiliki harapan utama pelayanan yang baik. Mulai dari pelayanan ketika pendaftaran hingga kebutuhan edukasi tambahan. Pelayanan yang baik akan berpengaruh secara signifikan terhadap kepuasan pengguna rumah sakit tersebut (Noor, 2018).

\section{Kesimpulan}

Preferensi (alasan memilih), persepsi (kelebihan dan kekurangan), dan harapan pasien dan pengunjung umum terhadap Rumah Sakit Ibu dan Anak (RSIA) hampir serupa, yaitu berdasarkan aspek nonarsitektural. Terdapat 1 (satu) perbedaan, yaitu persepsi pengunjung umum terhadap kekurangan RSIA, di mana persepsi tersebut termasuk di dalam aspek visual arsitektural. Kategori dengan korespondensi terbanyak pada seluruh aspek adalah aspek pelayanan. Kemudian di ikuti oleh fasilitas, kualitas tenaga medis, lokasi, dan parkir.

Dibanding penelitian tentang RSIA yang lain, penelitian ini berhasil mengungkap perbedaan preferensi, persepsi, dan harapan pengguna (pasien dan pengunjung umum) terhadap 3 (tiga) aspek, yaitu aspek non arsitektural, aspek non-visual arsitektural, dan aspek visual arsitektural. Kekurangan dari penelitian ini adalah penggunaan metode nonrandom sampling, di mana generalisasi lebih terbatas dibandingkan dengan random sampling, yang juga tidak berlaku untuk keseluruhannya.

Penelitian ini juga mengungkap evaluasi pengguna secara langsung. Di mana kategori tertinggi, yaitu pelayanan, fasilitas, kualitas tenaga medis, lokasi, dan parkir harus lebih diperhatikan ketika merencanakan bangunan RSIA. Untuk RSIA yang sudah ada, kategori-kategori tersebut dapat lebih ditingkatkan untuk mencapai kepuasan dan kenyamanan penggunanya. Selain itu, sebagai arsitek, 3 (tiga) aspek yang disebutkan diawal: aspek non arsitektural, aspek non-visual arsitektural, dan aspek visual arsitektural harus selaras dan menjadi satu kesatuan untuk mencapai RSIA yang baik dan ideal. Pada masa yang akan datang, dapat pula dilakukan penelitian lebih lanjut mengenai preferensi, persepsi, dan harapan pengguna terhadap RSIA dengan pertanyaan yang lebih spesifik

\section{Pernyataan penulis}

Dengan ini penulis menyatakan bahwa penelitian ini terbebas dari konflik kepentingan dengan pihak manapun

\section{Ucapan Terimakasih}

Para penulis mengucapkan terimakasih kepada Institut Teknologi Bandung dan semua pihak yang telah mendukung terlaksananya penelitian ini.

\section{Referensi}

Creswell, J. W. (2012). Qualitative Inquiry and Research Design: Choosing Among Five Approaches. SAGE Publications.

Creswell, J. W., \& Creswell, J. D. (2017). Research Design: Qualitative, Quantitative, and Mixed Methods Approaches. SAGE Publications.

Estiningtyas, A. (2010). Konsep Perencanaan Dan Perancangan Rumah Sakit Ibu \& Anak Penekanan Pada Psikologi Ibu Dan Anak Dengan Fasilitas Pelayanan Prima. Universitas Sebelas Maret.

Ginting, N., \& Priatna, B. D. (2019). Penataan Aspek Arsitektur Dan Visual Pada Kawasan Ekowisata Bukit Lawang. Talenta 
Conference Series: Energy and Engineering (EE), 2(1), Article 1. https://doi.org/10.32734/ee.v $2 \mathrm{i} 1.422$

Hirtanto, T., Ismiyati, I., \& Wardani, S. P. R. (2006). Analisis Kebutuhan Parkir Pada Rumah Sakit Umum Kelas B Di Kota Semarang. Media Komunikasi Dan Pengembangan Teknik Sipil, 15(1).

https://ejournal.undip.ac.id/in dex.php/pilar/article/view/47 27

Kumar, R. (2010). Research Methodology: A Step-by-Step Guide for Beginners. SAGE.

Kusumaningrum, A., \& Martiningrum, I. (2017). Persepsi Pengunjung terhadap Tingkat Kenyamanan Bnagunan Pelayanan Kesehatan (Studi Kasus: RSIA Melati Husada Kota Malang). Jurnal Mahasiswa Jurusan Arsitektur, 5(4).

Maslow, A. H. (2010). Toward A Psychology of Being-Reprint of 1962 Edition First Edition. Martino Publishing.

Maulana, Z. (2016). Pengaruh Kualitas Pelayanan Medis, Paramedis dan Penunjang Medis terhadap Kepuasaan Pasien Rawat Inap di Rumah Sakit Harapan Bunda Banda Aceh. Jurnal Manajemen Dan Keuangan, 5(1), 516-524.

Noor, Y. (2018). Kualitas Pelayanan Medis dan Kepuasan Pasien di Rumah Sakit Studi Empiris Kualitas Pelayanan Medis di RSIA Tiara Tangerang. Indonesian of Health Information Management Journal (INOHIM), 6(2), 46-54. https://doi.org/10.47007/inoh im.v6i2.6
Sutisna. (2001). Perilaku konsumen \& komunikasi pemasaran. PT Remaja Rosdakarya.

Wardhani, W., Sumarwan, U., \& Yuliati, L. N. (2015). Pengaruh Persepsi dan Preferensi Konsumen terhadap Keputusan Pembelian Hunian Green Product. Jurnal Manajemen Dan Organisasi, 6(1), 45-63. https://doi.org/10.29244/jmo. v6i1.12183

\section{Kontribusi Penulis}

Intan Reyndan Fananti berkontribusi dalam konseptualisasi, pengumpulan data dan investigasi, menyusun draft artikel dan editing.

Annisa Safira Riska berkontribusi pada pengumpulan data, analisis data, dan penyusunan draft artikel serta visualisasi data

Hanson Endra Kusuma berkontribusi pada metodologi, supervisi penelitian, validasi dan melakukan penelaahan artikel 